\title{
PENURUNAN KADAR KOLESTEROL TOTAL PADA MENCIT JANTAN PUTIH OLEH CINCAU KULIT BUAH NAGA MERAH
}

\section{Decrease of Total Cholesterol Levels in White Male Mice by Red Dragon Fruit Peel Grass Jelly}

\author{
Nela Agustin Kusuma Wardani*, Dinda Ina Sarinastiti, Putri Tari Indriani \\ Akademi Analis Farmasi dan Makanan Putra Indonesia Malang \\ Jl. Barito No. 5, Malang, 65126 \\ *Penulis Korespondensi, Email: nela.agustin.kw@gmail.com
}

\begin{abstract}
ABSTRAK
Kadar kolesterol tinggi dapat diturunkan dengan mengkonsumsi pangan fungsional berupa cincau kulit buah naga merah. Penelitian bertujuan membuktikan kemampuan cincau kulit buah naga merah dalam menurunkan kadar kolesterol pada mencit jantan putih hiperkolesterolemia. Metode penelitian ini adalah true experimental design dengan melakukan pengujian kolesterol total pada mencit sebelum dan sesudah perlakuan (pretest-posttest design). Pengkondisian hiperkolesterolmia dengan memberikan pakan tinggi kolesterol yaitu kuning telur puyuh secara oral pada kelompok 2, 3, dan 4 selama 15 hari. Selanjutnya selama 15 hari, kelompok 3 diberi simvastatin secara oral dengan dosis $0.10 \mathrm{mg} / \mathrm{kg}$ BB dan kelompok 4 diberi cincau kulit buah naga dengan dosis $0.26 \mathrm{mg} / \mathrm{kg}$ BB. Hasil penelitian menunjukkan pemberian cincau kulit buah naga merah dapat menurunkan kadar kolesterol total sebanyak $26.18 \%$. Sedangkan simvastatin hanya menurunkan kadar kolesterol total sebesar $11.77 \%$. Kesimpulannya bahwa pemberian cincau kulit buah naga merah dapat menurunkan kadar kolesterol total.

Kata kunci: Cincau, Kolesterol total, Kulit buah naga merah

\section{ABSTRACT}

High cholesterol levels was reduced by consuming functional food in the form of red dragon fruit peel grass jelly. This study aims to prove red dragon fruit peel grass jelly to reduce cholesterol levels in white male hypercholesterolemia mice. This study method is a true experimental design by testing total cholesterol in mice before and after treatment. Conditioning hypercholesterolemia by giving quail egg yolks orally in groups 2, 3, and 4 for 15 days. Then for 15 days, group 3 was given simvastatin orally (a dose of $0.10 \mathrm{mg} / \mathrm{kg}$ bw) and group 4 was given red dragon fruit peel grass jelly (a dose of $0.26 \mathrm{mg} / \mathrm{kg} \mathrm{bw}$ ). The results showed that red dragon fruit peel grass jelly reduce total cholesterol levels by $26.18 \%$. While simvastatin only reduce total cholesterol by $11.77 \%$. The conclusion is giving red dragon fruit peel grass jelly can reduce total cholesterol levels.
\end{abstract}

Key words: Grass jelly, Red dragon fruit peel, Total cholesterol

\section{PENDAHULUAN}

Peningkatan kadar kolesterol total darah diatas nilai normal disebut hiperkolesterolemia. Menurut Matondang (2017), kolesterol total dalam darah dapat meningkat sebesar 2-3 mg/dl 
jika diiringi konsumsi lemak jenuh dan kolesterol (100 mg/hari). Pengobatan hiperkolesterolemia dapat diobati dengan obat sintetis. Obat golongan statin diketahui memiliki efek samping pada pasien penderita penyakit kardiovaskular dan hiperolesterolemia yang mendapatkan terapi statin. Sekitar 10-25\% pasien yang mendapatkan terapi statin dilaporkan mengalami Statinassociated muscle symptoms (SAMS). Sedangkan berdasarkan survei internet, $60 \%$ pengguna obat statin melaporkan kejadian SAMS dan $60 \%$ lainnya dilaporkan menghentikan penggunaan obat ini karena efek sampingnya (Thompson et al., 2016). Selain itu, hiperkolesterolemia dapat diobati dengan pangan fungsional untuk menurunkan kadar kolestrol yang tinggi. Salah satunya dengan memanfaatkan kulit dari buah naga merah (Hylocereus polyrhizus).

Buah naga merah (Hylocereus polyrhizus) memiliki kulit dengan berat 30-35\% dari berat buahnya (Faadlilah, 2016). Kulit buah ini biasanya dimanfaatkan sebagai sirup, jus, es krim, permen, dan cookies (Rochmawati, 2019). Menurut (Faadlilah, 2016 dan Putri, 2017), kandungan kulit buahnya yaitu total flavonoid $8.33 \mathrm{mg} / 100 \mathrm{~g}$, total fenol $39.70 \mathrm{mg} / 100 \mathrm{~g}$, dan betasianin $13.80 \mathrm{mg}$. Selain itu, kulitnya mengandung antioksidan. Antioksidan memiliki peran dalam penghambatan peroksidasi lemak serta radikal bebas. Sumber antioksidan didapat dari kandungan flavonoid sebesar $8.33 \mathrm{mg} / 100 \mathrm{~g}$ (Faadlilah, 2016).

Pada kulit buah naga merah juga terdapat kandungan serat kasar sebesar $3.60 \%$ (Wardani dkk., 2018) dan serat pangan sekitar 46.70\% (Waladi et al., 2015). Serat pangan dapat bermanfaat untuk mengontrol obesitas, diabetes, gangguan pencernaan, kanker kolon, serta menurunkan kadar kolesterol dalam darah (Waladi et al., 2015). Asam empedu, kolesterol, dan lemak akan diikat oleh serat pangan pada usus halus. Asam empedu yang tidak diserap usus halus akan dibuang melalui usus besar. Untuk menggantikan asam empedu, hati akan menarik kolesterol dari darah yang mengakibatkan kolesterol dalam dari menurun.

Menurut Faadlilah (2016), tikus dislipidemia yang diberi kulit buah naga merah yang diseduh (14 hari) mengalami peningkatan jumlah kolesterol HDL sebesar $25.2 \%$ (dosis pemberian $200 \mathrm{mg} / \mathrm{ml}$ ), 66\% (dosis pemberian $400 \mathrm{mg} / \mathrm{ml}$ ), dan 105\% (dosis pemberian 800 $\mathrm{mg} / \mathrm{ml}$ ). Menurut Septiana (2016) tikus dislipidemia yang diberi kulit buah naga merah yang diseduh (14 hari) dapat menurunkan nilai MDA pada plasma dengan rerata nilai MDA sebanyak $3.3 \pm 0.17 \mathrm{nmol} / \mathrm{ml}$ (dosis pemberian $200 \mathrm{mg} / \mathrm{ml}$ ), $2.1 \pm 0.22 \mathrm{nmol} / \mathrm{ml}$ (dosis pemberian 400 $\mathrm{mg} / \mathrm{ml}$ ) dan $1.7 \pm 0.18 \mathrm{nmol} / \mathrm{ml}$ (dosis pemberian $800 \mathrm{mg} / \mathrm{ml}$ ). Oleh karena, itu perlu pengolahan lebih lanjut tentang pangan fungsional pada kulit buah naga sebagai penurun kadar kolesterol. Salah satu pengolahan pangan fungsionalnya dengan diolah menjadi cincau kulit buah naga merah.

Cincau umumnya diolah secara tradisional. Gel cincau hitam (Mesona palustris) didapatkan melalui proses sinergistik dari koloid pembentuk gel (mirip massa agar-agar), pati, dan mineral yang berasal dari abu qi (Fahrial, 1999). Cincau dari bagian kulit pada buah naga merah dibuat melalui proses ekstrasi untuk mendapatkan sari kulit buah naga merah lalu ditambahkan karagenan sebagai bahan pembentuk gel. Cincau yang dihasilkan memiliki warna merah alami dari antosianin. Dipilih cincau sebagai pangan fungsional karena pada kulit buah ini terdapat pektin yang bisa digunakan untuk pembentuk gel dan pada pembuatan cincau ditambahkan karagenan. Karagenan memiliki kemampuan menghambat absorpsi kolesterol di usus serta meningkatkan ekskeresi asam empedu. Penghambatan absorpsi ini berkaitan dengan kemampuan karagenan dalam meningkatkan viskositas lumen usus dan mengganggu pembentukan misel, serta meningkatkan ekskresi asam empedu, karagenan yang larut dapat mengikat asam empedu (Wolever et al., 1997).

Oleh karena itu, diperlukan penelitian lebih lanjut terhadap kadar kolesterol total pada mencit jantan putih hiperkolesterolemia yang diberi cincau kulit dari buah naga merah. 


\section{BAHAN DAN METODE}

\section{Bahan}

Sampel cincau tiruan kulit buah naga merah (Wardani dkk., 2018), simvastatin, mencit jantan putih, pakan standar (PARS), pakan tinggi kolesterol (kuning telur puyuh), sekam, dan aquades.

Alat

Alat dalam penelitian ini adalah kandang mencit, sarung tangan, masker, wadah pakan, botol minum, alat sonde, dan alat ukur kolesterol Easy Touch GCU (gula darah, kolesterol, dan asam urat).

\section{Desain Penelitian}

True experimental design dengan melakukan pengujian kolesterol total pada mencit sebelum dan sesudah perlakuan (pretest-posttest design). Data yang diperoleh dari parameter uji setelah pemberian pakan tinggi kolesterol dan data setelah masa perlakuan yaitu kolesterol total. Data lalu dianalisis dengan One-Way ANOVA selang kepercayaan 5\%.

\section{Tahapan Penelitian}

Tahapan persiapan dalam penelitian ini meliputi hewan uji (mencit jantan putih) yang digunakan berumur 8-12 minggu, berat badan 20-30 g, sehat dan tidak ada bagian tubuh yang malfungsi. Persiapan untuk tahap pelaksanaan yaitu pakan standar (PARS), kuning telur puyuh (untuk mengkondisikan hiperkolesterol), cincau kulit buah naga merah (untuk menurunkan hiperkolesterol sebagai pangan fungsional), dan obat simvastatin (untuk menurunkan hiperkolesterol).

Tahap pelaksanaan meliputi aklimatisasi hewan uji (3 hari). Hewan uji dibagi menjadi 4 kelompok (5 ekor/kelompok). Pengkondisian hiperkolesterol dengan pakan tinggi kolesterol selama 15 hari (kelompok 2, 3, dan 4). Kelompok 1 diberi pakan standar. Lalu dilakukan pengukuran kadar kolesterol total awal. Setelah itu, pemberian perlakuan dilakukan dalam 15 hari (kelompok 2, 3, dan 4), serta dilakukan pengukuran kadar kolesterol total akhir. Pengolahan analisis data berdasarkan hasil penelitian yang diperoleh.

\section{Metode \\ Pembuatan Cincau Kulit Buah Naga Merah (Wardani dkk., 2018)}

Sebanyak $500 \mathrm{~g}$ kulit buah naga merah dipotong kecil kemudian ditambahkan air sebanyak $1 \mathrm{~L}$. Kemudian, dilakukan proses blansing $\left(70^{\circ} \mathrm{C} ; 5\right.$ menit), lalu diblender sampai hancur lalu disaring dan didiamkan 15 menit. Setelah dingin ditambahkan karagenan, CMC-Na dan gula dengan perbandingan (1: $1.5: 0.5)$ dari jumlah sari kulit buah naga merah, diaduk hingga homogen. Campuran larutan tersebut dimasak pada suhu selama 10-15 menit hingga mencapai suhu $100^{\circ} \mathrm{C}$, kemudian dicetak.

\section{Pengelompokan Hewan Coba}

Mencit jantan putih sebanyak 20 ekor dibagi menjadi 4 kelompok (perkelompok 5 ekor). Kelompok 1 adalah perlakuan normal yaitu tidak diberikan perlakuan apapun. Kelompok 2 adalah kontrol negatif (diberi pakan tinggi kolesterol), kelompok 3 adalah kontrol positif (diberi pakan tinggi kolesterol dan diberikan obat simvastatin), dan kelompok 4 adalah perlakuan yang diberi pakan tinggi kolesterol dan diberikan cincau kulit buah naga merah. 


\section{Pembuatan Pakan Tinggi Kolesterol}

Pakan tinggi kolesterol digunakan untuk meningkatkan kadar kolesterol yang diberikan setiap hari secara oral (sonde) selama 15 hari. Pakan tinggi kolesterol yang digunakan adalah kuning telur puyuh yang mengandung kadar kolesterol sebanyak $2138.17 \mathrm{mg} / 100 \mathrm{~g}$ (Pamungkas et al., 2013). Asupan lemak yang aman untuk manusia adalah $\leq 300 \mathrm{mg}$ per hari.

Pada penelitian ini hewan uji (mencit) akan diberikan asupan lemak dua kali lipat dari anjuran diatas lalu dikalikan dengan faktor konversi (manusia ke mencit), yaitu $600 \mathrm{mg} \times 0.0026$ $=1.56 \mathrm{mg}$ lemak. Jika $100 \mathrm{~g}(100000 \mathrm{mg})$ kuning telur puyuh setara dengan $2138.17 \mathrm{mg}$ kolesterol, maka asupan pakan yang diberikan sejumlah $73 \mathrm{mg}$ kuning telur puyuh per hari.

Pakan tinggi kolesterol yang diberikan disesuaikan dengan kapasitas lambung mencit yaitu $0.5 \mathrm{ml}$, sehingga suspensi yang dibuat dengan mencampurkan $7.3 \mathrm{~g}$ kuning telur puyuh dengan akuades sampai $50 \mathrm{ml}$. Volume pemberian pada mencit sebesar $0.5 \mathrm{ml} / \mathrm{hari}$.

\section{Perhitungan Dosis Obat Simvastatin}

Dosis yang digunakan pada manusia adalah $40 \mathrm{mg} /$ hari. Faktor konversi berat badan dari manusia $(70 \mathrm{~kg}) \mathrm{ke}$ mencit $(20 \mathrm{~g})$ adalah 0.0026 . Dosis $=40 \mathrm{mg} / \mathrm{hari} \times 0.0026=0,10 \mathrm{mg} / \mathrm{hari}$. Dosis yang digunakan untuk mencit jantan putih setiap harinya adalah $0.10 \mathrm{mg} / \mathrm{hari}$ selama 15 hari.

\section{Perhitungan Dosis Cincau Kulit Buah Naga Merah}

Dosis yang digunakan adalah $100 \mathrm{mg}$ produk $\times 0.0026=0.26 \mathrm{mg}$.

\section{Prosedur Analisis}

Makanan yang diberikan adalah pakan PARS dengan pemberian air minum secara adlibitum. Setelah proses aklimatisasi, dilakukan pengkondisian hiperkolesterol dengan memberikan pakan tinggi kolesterol yaitu kuning telur puyuh secara oral (sonde) untuk kelompok 2, 3, dan 4 selama 15 hari. Kelompok 1 tidak diberi perlakuan apapun sampai akhir penelitian.

Kemudian, hewan uji dipuasakan 8-12 jam untuk persiapan pengambilan sampel darah. Sampel darah digunakan pada pengukuran kadar kolesterol total awal. Kapas yang diberi alkohol $70 \%$ digunakan untuk membersihkan ekor hewan uji. Darah diambil pada bagian ekor yang telah ditusuk (beberapa tetes), kemudian diteteskan pada strip kolesterol. Kadar total kolesterol didapatkan dengan menggunakan alat ukur Easy Touch GCU (gula darah, kolesterol, dan asam urat) dengan detection limit 100-400 $\mathrm{mg} / \mathrm{dL}$.

Selanjutnya, dilakukan pemberian simvastatin secara oral (kelompok 3) dan cincau kulit buah naga merah secara oral (kelompok 4) selama 15 hari. Pada akhir penelitian dilakukan pengambilan darah (kelompok 1, 2, 3, dan 4) untuk mendapatkan kadar kolesterol total akhir.

\section{HASIL DAN PEMBAHASAN}

Penurunan kadar kolesterol total mencit pada awal dan akhir perlakuan dapat dilihat pada Tabel 1. Hasil dari pengukuran penurunan kadar kolesterol terhadap mencit jantan putih dengan cincau kulit buah naga, kelompok 2, 3, dan 4 dapat menurunkan hiperkolesterolemia. Namun, kelompok 4 memiliki persen penurunan paling banyak yaitu $26.18 \%$. Penurunan ini dikarenakan kandungan antioksidan kulit buah naga merah dapat menurunkan kolesterol dalam darah. Selain itu, terdapat kandungan serat pangan sebanyak $46.70 \%$ (Saneto, 2005) yang dapat mengontrol berat badan atau kegemukan, serta mengurangi tingkat kolestrol dalam darah. 
Tabel 1. Kadar Kolesterol Total (mg/dl) Mencit Jantan Putih Awal dan Akhir Perlakuan

\begin{tabular}{cccc}
\hline Kelompok & \multicolumn{2}{c}{ Kadar Kolesterol Total (mg/dl) } & \multirow{2}{*}{ \% Penurunan } \\
\cline { 2 - 3 } & Awal & Akhir & \\
\hline 1 & $-\mathrm{LO}-$ & $-\mathrm{LO}-$ & - \\
2 & $140 \mathrm{mg} / \mathrm{dL} \pm 1.89 \mathrm{a}$ & $137.33 \mathrm{mg} / \mathrm{dL} \pm 3.77 \mathrm{c}$ & 1.90 \\
3 & $145.83 \mathrm{mg} / \mathrm{dL} \pm 3.97 \mathrm{~b}$ & $128.67 \mathrm{mg} / \mathrm{dL} \pm 3.20 \mathrm{~b}$ & 11.77 \\
4 & $154 \mathrm{mg} / \mathrm{dL} \pm 3.52 \mathrm{c}$ & $113.67 \mathrm{mg} / \mathrm{dL} \pm 3.82 \mathrm{a}$ & 26.18 \\
\hline
\end{tabular}

Keterangan :

- - LO- (kadar kolesterol total dibawah $100 \mathrm{mg} / \mathrm{dl}$ )

- Awal (setelah pengkondisian hiperkolesterol selama 15 hari)

- Akhir (setelah pemberian simvastatin dan cincau kulit buah naga merah selama 15 hari)

- Beda nyata ditunjukkan dengan notasi yang berbeda antar perlakuan ( $\alpha=0.05)$

Kulit buah naga merah mengandung niasin, vitamin $C$, dan serat pangan (pektin) yang dapat menurunkan kadar trigliserida dan kolesterol darah (Kristanto, 2008). Menurut (Heryani, 2016) jika menggunakan ekstrak kulit buah naga merah dalam dosis $13 \mathrm{mg} /$ hari selama 15 hari dapat menurunkan kolesterol sebanyak $24.93 \%$. Pada proses pembuatan cincau diberikan bahan lain yaitu karagenan. Karagenan memiliki kemampuan menghambat absorpsi kolesterol di usus serta meningkatkan ekskresi asam empedu. Penghambatan absorpsi ini berkaitan dengan kemampuan karagenan dalam meningkatkan viskositas lumen usus dan mengganggu pembentukan misel, serta meningkatkan ekskresi asam empedu, karagenan yang larut dapat mengikat asam empedu (Wolever et al., 1997). Menurut (Subroto, 2011), pemberian 10\% karagenan kedalam $100 \%$ bahan makanan dapat menurunkan kadar kolesterol sebanyak $47.76 \%$.

Pada kelompok 3 juga mengalami penurunan yaitu $11.77 \%$. Pemilihan obat simvastatin karena termasuk golongan obat statin dengan menghambat enzim yang diperlukan tubuh untuk memproduksi kolesterol. Mekanisme kerjanya dengan menghambat kinerja enzim 3-hydroxy-3methylglutaryl coenzyme A reductase (HMG CoA-reduktase) (Rosita dan Andrajati, 2014). Keunggulan dari obat simvastatin ini adalah kadar kolesterol total dapat turun sebanyak $20 \%$, serta terjadi penurunan resiko penyakit pembuluh darah sampai $24 \%$ pada dosis $40 \mathrm{mg} / \mathrm{hari}$ (Adesta et al., 2010).

Pada kelompok 2 masih terdapat penurunan meskipun hanya sedikit yaitu $1.90 \%$. Pada kelompok 2 setelah diberi perlakuan tinggi kolesterol tidak diberi obat maupun cincau kulit buah naga. Penurunan ini dapat disebabkan karena mencit termasuk hewan yang memiliki kondisi tubuh yang baik dan dapat memperbaiki diri sendiri (Rakhmadi, 2009). Penurunan ini juga dapat disebabkan oleh makanan yang dimakan oleh mencit setiap harinya yaitu pakan pollard. Pakan pollard mengandung vitamin, serat kasar dan protein kasar yang juga dapat menurunkan kadar total kolesterol (Susanti, 2007).

Keterbatasan pada penelitian ini yaitu pemeriksaan kadar kolesterol memakai alat Easy Touch GCU yang memiliki rentang kadar kolesterol terbaca oleh alat hanya sebesar 100-400 $\mathrm{mg} / \mathrm{dl}$, sehingga jika kadar kolesterol dibawah $100 \mathrm{mg} / \mathrm{dl}$ alat akan menampilkan tulisan -LO-. Sampel yang digunakan adalah 1 tetes darah segar yang diletakkan pada strip pengujian kolesterol. Pengujian menggunakan alat ini lebih murah dan mudah dilakukan untuk mendeteksi kadar kolesterol total.

Hal ini berbeda dengan pengujian kolesterol total menggunakan metode CHOD-PHP yaitu kadar kolesterol dapat ditentukan setelah hidrolisis enzimatis dan oksidasi. Sampel yang digunakan yaitu sampel serum atau plasma darah. Hasil pengujian kolesterol menggunakan metode ini lebih akurat karena menggunakan indikator quinoneimine yang terbentuk dari 
hydrogen peroxidase dan 4-aminoantipyrin dengan adanya phenol dan peroxidase (Widada dkk., 2016). Pengujian menggunakan metode ini lebih mahal dan membutuhkan waktu lebih lama untuk mendapatkan hasil kadar kolesterol total dibandingkan dengan memakai Easy Touch GCU.

\section{SIMPULAN}

Kesimpulan penelitian ini yaitu kadar kolesterol total pada mencit (Mus musculus) hiperkolesterolemia dapat diturunkan sebanyak $26.18 \%$ dengan pemberian cincau kulit buah naga merah (Hylocereus polyrhizus) dengan dosis 0.26 mg/ekor/hari selama 15 hari.

\section{UCAPAN TERIMA KASIH}

Ucapan terima kasih ditujukan pada Akademi Analis Farmasi dan Makanan (AKAFARMA) Putra Indonesia Malang yang telah memberikan bantuan sarana dan prasarana untuk keterlaksanaan penelitian ini.

\section{DAFTAR PUSTAKA}

Adesta, F. E., Rahmawati, D., \& Surastri, B. 2010. Pengaruh Pemberian Simvastatin terhadap Fungsi Memori Jangka Pendek Tikus Wistar Hiperlipidemi. Fakultas Kedokteran, Universitas Diponegoro. 1-15.

Faadlilah, N. 2016. Efek Pemberian Seduhan Kulit Buah Naga Merah ( Hylocereus polyrhizus) Terhadap Kadar Kolesterol HDL (High Density Lipoprotein). Skripsi. Universitas Diponegoro Semarang.

Fahrial. 1999. Mempelajari Proses Pembuatan Cincau Hitam (Mesona palustris BL) Instan Dan Pengaruhnya Terhadap Produksi Radikal Bebas Makrofag Mencit Sebagai Indikator Imunostimulan secara In Vivo. Skripsi. Institut Pertanian Bogor.

Heryani, R. 2016. Pengaruh Ekstrak Buah Naga Merah Terhadap Profil Lipid Darah Tikus Putih Hiperlipidemia. STIKes Pekanbaru Medical Center, Pekanbaru Riau.

Kristanto. 2008. Buah Naga Pembudidayaan di Pot dan di Kebun.Penebar Swadaya. Jakarta.

Matondang, N. 2017. Pengaruh Pemberian Sari Belimbing Wuluh (Averrhoa bilimbi. L) Terhadap Kadar Kolesterol Total Wanita Dewasa. JNH (Journal of Nutrition and Health) 5(3): 2-17.

Pamungkas, R. A., Sugeng, R. S., \& Warsito, S. 2013. Pengaruh Level Etanol Dan Lama Maserasi Kuning Telur Puyuh Terhadap Kolesterol Total, HDL, Dan LDL. Jurnal Imiah Peternakan. 1 (3): 1136-1142.

Putri, Tatania T. 2017. Uji Efektivitas Ekstrak Buah Naga Merah (Hylocereus polyrhizus) Dan Simvastatin Terhadap Penurunan Kadar Kolesterol Total Mencit Jantan (Mus musculus L.) Hiperkolesterolemia. Skripsi. Universitas Lampung.

Rakhmadi, I dkk. 2009. Performa Mencit Jantan (Mus musculus) Umur 28-63 Hari pada Alas Kandang Sekam, Pasir Dan Zeolit Dengan Dan Tanpa Sekat Alas. Jurnal Zeolit Indonesia. Vol 8 No. 2, 53-65

Rosita, I., Andrajati, R. dan Zainuddin. 2014. Efek Samping Nyeri Otot dari Simvastatin dan Atorvastatin pada Pasien Jantung RSUD Tarakan. Fakultas Farmasi, Universitas Indonesia.

Rochmawati, N. 2019. Pemanfaatan Kulit Buah Naga Merah (Hylocereus polyrhizus) Sebagai Tepung Untuk Pembuatan Cookies. Jurnal Pangan dan Agroindustri Vol.7 No.3: $19-24$ 
Saneto, B. 2005. Karakterisasi Kulit Buah Naga Merah (Hylocereus polyrhizus). Jurnal Agarika. Vol 2:143-149

Septiana, WC. dan Ardiaria, M. 2016. Efek Pemberian Seduhan Kulit Buah Naga Merah (Hylocereus polyrhizus) terhadap Kadar Malondialdehid (MDA) Tikus Sprague Dawley Dislipidemia. Journal of Nutrition College. 5(4), 344-352.

Subroto, T. 2011. Efek Anti Hiperkolesterolemik Karagenan Rumput Laut dalam Diet Terhadap Plasma Lipid Tikus Putih. Fakultas MIPA Universitas Padjadjaran. Vol. 13 No. 1

Susanti, S. dan Marhaeniyanto E. 2007. Kecernaan, Retensi Nitrogen dan Hubungannya dengan Produksi Susu pada Sapi Perankan Frisien Holstein (PFH) yang diberi Pakan Pollard dan Bekatul. Fakultas Peternakan Universitas Tribhuwana Tunggadewi. Vol. 15 No. 2

Thompson, Paul D., Gregory P., Amanda Z. and Beth T. 2016. Statin-Associated Side Effects. Journal of the American College of Cardiology. Volume 67, Issue 20, Pages 2395-2410

Waladi, Vonny, S., and Faizah, H. 2015. Utilization of Red Dragon Fruit Pell (Hylocereus polyhizus) As an Additive in the Making of Ice Cream. International Journal Of Pharmaceutical Sciences And Research. 6(10): 1-11

Wardani, N.A.K., Indriani P.T. dan Sarinastiti D.I. 2018. Karakteristik Fisik dan Kimia Cincau Tiruan dari Kulit Buah Naga Merah (Hylocereus polyrhizus). Jurnal Ilmu dan Teknologi Hasil Ternak. Vol 13 No. 2, 98-107

Widada, S., Martsiningsih, M., dan Carolina, S. 2016. Gambaran Perbedaan Kadar Kolesterol Total Metode CHOD-PAP (Cholesterol Oxidase - Peroxsidase Aminoantypirin) Sampel Serum dan Sampel Plasma EDTA. Jurnal Teknologi Laboratorium, 5 (1), 41-44

Wolever, T.M.S., Hegele R.A., Connelly P.W., Ransom T.P., Story J.A., Furumoto E.J. dan Jenskins D.J. 1997. Longterm Effect of Soluble-Fiber Foods on Postprandial Fat Metabolism in Dyslipidemic With Apo E3 and Apo E4 Genotypes. American Journal of Clinical Nutrition, 66, 584-590 